\title{
PERBEDAAN TINGKAT ASUPAN ENERGI DAN LEMAK SERTA AKTIVITAS FISIK BERDASARKAN STATUS OBESITAS SENTRAL PADA PASIEN RAWAT JALAN DI RSUD WANGAYA, KOTA DENPASAR
}

\author{
I Wayan Ambartana', Ni Wayan Anita Sukma Andari² \\ 1Poltekkes Denpasar Jurusan Gizi \\ ${ }^{2}$ RSUD Wangaya Denpasar \\ wayanambartana@yahoo.co.id
}

\section{ABSTRAK}

Kejadian obesitas sentral dapat terjadi karena adanya perubahan gaya hidup seperti tingginya konsumsi minuman beralkohol, kebiasaan merokok, tingginya konsumsi makanan berlemak, rendahnya konsumsi sayuran dan buah, dan kurangnya aktivitas fisik. Tujuan penelitian ini adalah untuk mengetahui perbedaan tingkat konsumsi energi, lemak dan aktivitas fisik berdasarkan status obesitas sentral pada pasien rawat jalan di RSUD Wangaya. Penelitian ini merupakan penelitian observasional dengan rancangan kasus kontrol. Populasi adalah semua pasien yang berkunjung ke Poliklinik RSUD Wangaya dan sampel adalah pasien laki - laki dan perempuan berumur di atas $\mathbf{2 0}$ tahun dan tidak memiliki penyakit komplikasi berat. Data diperoleh dengan metode wawancara dan pencatatan hasil pengukuran. Berdasarkan hasil analisis uji statistik Independent t-test disimpulkan bahwa terdapat perbedaan yang signifikan antara tingkat konsumsi energi $(p=0,019)$ dan tingkat konsumsi lemak $(p=0,047)$ berdasarkan status obesitas sentral. Terdapat pula perbedaan yang signifikan antara aktivitas fisik $(p=0,006)$ berdasarkan status obesitas sentral. Disarankan kepada pasien dengan risiko obesitas sentral untuk menjaga pola makan, gaya hidup dan aktivitas fisik sehingga penyakit degeneratif yang timbul akibat obesitas dapat dihindari.

Kata kunci: asupan energi, asupan lemak, aktifitas fisik, obesitas sentral

\section{ABSTRACT}

\section{DIFFERENCES IN ENERGY AND FAT INTAKES, PHYSICAL ACTIVITY BASED ON CENTRAL OBESITY STATUS IN OUTPATIENTS IN WANGAYA HOSPITAL, DENPASAR CITY}

Riskesdas 2010 stated that the national prevalence of central obesity reached 18.8 percent for those aged $\geq 15$ years and Bali is one of 17 provinces which had a prevalence of central obesity above the national prevalence, it was 22 percent. The purpose of the study was to determine differences in the level of energy and fat intakes, and physical activity by central obesity status in outpatients in Wangaya hospital. This study is an observational study with case-control design. The population was all patients who visited the polyclinic in Wangaya Hospital and the sample was male patients and female aged $>20$ years and did not have severe complications of disease. Data were obtained by interviewing and recording the measurement's results. Based on the statistical tests analysis usinglndependent t-test concluded that there were significant differences between the level of energy consumption $(p=0.019)$ and fat $(p=0.047)$ based on the status of central obesity. There were a significant difference between physical activity $(p=$ 0.006 ) based on the status of central obesity. It is suggested to patient with the risk of central obesity to maintain good food pattern, good lifestyle and do physical avtivity regularly to avoid degenerative diseases.

Keywords: energy intake, fat intake, physical activity, central obesity

\section{PENDAHULUAN}

$\mathrm{M}$

asalah obesitas telah menjadi masalah kesehatan dan gizi masyarakat di dunia. Obesitas tidak menyebabkan kematian secara langsung, tetapi menyebabkan masalah kesehatan yang serius yang dapat memicu kelainan kardiovaskuler, ginjal, metabolik, protombik dan respon inflamasi.

Prevalensi obesitas sentral pada penduduk Eropa dan Asia mengalami peningkatan. Prevalensi obesitas sentral pada laki-laki meningkat dari 37 persen (periode 1999-2000) 
menjadi 42,2 persen (periode 2003-2004), sedangkan prevalensi obesitas sentral pada perempuan meningkat dari 55,3 persen menjadi 61,3 persen pada periode yang sama ${ }^{4}$

Hasil Riskesdas 2010 menyebutkan bahwa prevalensi obesitas sentral nasional mencapai $18,8 \%$ untuk umur $\geq 15$ tahun dan Bali merupakan salah satu dari 17 provinsi yang memiliki prevalensi obesitas sentral di atas prevalensi nasional yaitu 22 persen.

Menurut data Dinas Kesehatan Provinsi Bali 2009, di Indonesia khususnya di Bali prevalensi obesitas mencapai angka 9,8 persen dari total penduduk Bali, dimana prevalensi tertinggi terdapat di wilayah Kota Denpasar yaitu 15,2 persen. Hasil tersebut diikuti pula dengan prevalensi tingkat konsumsi makanan berlemak tertinggi terdapat di Kota Denpasar juga mencapai angka tertinggi yaitu 27,1 persen untuk konsumsi makanan berlemak dibandingkan dengan Kabupaten lainnya. RSUD Wangaya sebagai salah satu rumah sakit pemerintah di Kota Denpasar yang melayani pasien yang bertempat tinggal di wilayah Denpasar dan Badung, selama Triwulan kedua April - Juni 2013 telah melayani 9048 orang pasien yang memeriksakan diri ke Poliklinik Interna dengan berbagai jenis penyakit yang diderita.

Berdasarkan uraian di atas maka peneliti tertarik untuk meneliti perbedaan antara tingkat konsumsi energi, lemak dan aktivitas fisik berdasarkan status obesitas sentral pada pasien rawat jalan di RSUD Wangaya Kota Denpasar.

Tujuan penelitian adalah menentukan tingkat konsumsi energi dan lemak, menentukan tingkat aktivitas fisik, menganalisis perbedaan tingkat asupan energi, lemak dan aktivitas fisik berdasarkan status obesitas sentral pasien rawat jalan di RSUD Wangaya Kota Denpasar.

\section{METODE}

\section{Jenis dan Rancangan}

Jenis penelitian adalah penelitian observasional. Sedangkan rancangan adalah rancangan case control study yaitu subyek penelitian dibagi menjadi dua kelompok yaitu kelompok kasus adalah penderita obesitas sentral dan kelompok kontrol adalah bukan penderita obesitas sentral.

\section{Tempat dan Waktu}

Penelitian ini dilaksanakan di RSUD Wangaya Kota Denpasar pada Bulan Agustus sampai Bulan Oktober 2013.

\section{Populasi dan Sampel}

Populasi dalam penelitian ini adalah semua pasien yang menjalani rawat jalan di RSUD Wangaya Denpasar, sedangkan sampel adalah bagian dari populasi yang memenuhi kriteria sebagai berikut: pasien rawat jalan dengan status obesitas sentral, baik laki-laki atau perempuan berumur $>20$ tahun, tidak menderita penyakit komplikasi berat, bertempat tinggal di wilayah Denpasar dan Badung. Adapun yang disebut mempunyai obesitas sentral (lingkar perut/LP) adalah untuk laki-laki dengan $\mathrm{LP}>90 \mathrm{~cm}$ atau perempuan dengan LP $>80 \mathrm{~cm}$. Besar sampel didasarkan pada perkiraan proporsi populasi yaitu pasien obesitas sentral sebesar 22 persen, dengan tingkat kepercayaan sampel sebesar $95 \%$. Dari perhitungan sampel didapatkan jumlah sampel adalah 30 orang yang menderita obesitas sentral, sebagai pembanding diambil juga 30 orang yang tidak menderita obesitas sentral. ${ }^{5}$

Teknik pengambilan sampel ditentukan dengan metode konsekutif yaitu setiap pasien yang datang ke Poliklinik interna(Penyakit Dalam) RSUD Wangaya selama Bulan Agustus sampai Bulan Oktober 2013 yang memenuhi kriteria insklusi diambil sebagai sampel Kasus, sedangkan yang tidak memenuhi kriteria inklusi diambil sebagai sampel Kontrol, sampai jumlah sampel terpenuhi yaitu 30 sampel obesitas sentral dan 30 sampel non obesitas sentral (kontrol).

\section{Jenis dan Cara Pengumpulan Data}

Data primer yaitu data identitas sampel meliputi nama, tanggal lahir atau umur, jenis kelamin, pekerjaan, pendidikan dan alamat diperoleh dengan cara wawancara. Data berat badan diperoleh dengan pengukuran menggunakan timbangan badan Camry dengan kapasitas $120,0 \mathrm{~kg}$ dan ketelitian 0,1 kg. Data tinggi badan diukur menggunakan mikrotoise Onemed dengan kapasitas 200,0 cm dan ketelitian $0,1 \mathrm{~cm}$. Data konsumsi sampel diperoleh dengan cara wawancara dengan menggunakan form Semi Quantitatif Food Frequency Questionaire (SQ-FFQ). Data aktivitas fisik diperoleh dengan cara wawancara 
mengenai kegiatan sampel selama 1 hari (24 jam). Data yang dikumpulkan meliputi jenis, lama dan frekuensi kegiatan yang dilakukan sampel. Data pengukuran lingkar perut diperoleh dengan menetapkan terlebih dahulu titik tulang rusuk bawah terakhir dan titik ujung lengkung paha atau panggul, setelah itu tentukan titik tengah diantara keduanya kemudian lakukan pengukuran secara horizontal melingkari titik tengah perut tersebut.

Data sekunder yang dikumpulkan meliputi data gambaran umum rumah sakit yang diperoleh dari bagian informasi RSUD Wangaya Kota Denpasar.

\section{Alat dan Instrumen Penelitian}

Alat yang digunakan dalam penelitian ini adalah meterline dengan ketelitian $0,1 \mathrm{~cm}$, timbangan injak merk Camry dengan ketelitian $0,1 \mathrm{~kg}$, microtoise merk Onemed dengan ketelitian $0,1 \mathrm{~cm}$, kalkulator, dan alat tulis. Sedangkan instrumen yang digunakan adalah form identitas sampel, form SQ-FFQ, dan form aktivitas fisik.

\section{Pengolahan Data}

Data tingkat konsumsi energi dan lemak

Data konsumsi masing-masing bahan makanan dalam URT dikumpulkan dengan wawancara menggunakan form SQ-FFQ, selanjutnya dikonversikan ke dalam bentuk gram. Apabila ada frekuensi penggunaan bahan makanan dalam minggu atau bulan maka sebelumnya dirata-ratakan dengan membagi sesuai jumlah hari dalam minggu atau bulan tersebut sehingga didapatkan berat gram dalam satu hari. Setelah itu dianalisis menggunakan program Nutrisurvey sehingga didapat jumlah konsumsi energi dan lemak dalam satu hari. Hasil konsumsi energi dan lemak sehari berdasarkan wawancara tersebut selanjutnya dibandingkan dengan hasil perhitungan kebutuhan energi dan lemak sehari sehingga diperoleh tingkat asupan energi dan lemak sampel. Kebutuhan energi dan lemak sampel dihitung menggunakan rumus Harris Benedict.

\section{Data aktivitas fisik}

Data aktivitas fisik diperoleh dengan merinci semua jenis dan lamanya kegiatan yang dilakukan selama 24 jam (dalam menit) pada lembar kuesioner. Semua aktivitas sampel yang telah dirinci kemudian dikonversikan menjadi perkiraan keluaran energi perhari menggunakan Daftar Nilai Perkiraan Keluaran Energi berdasarkan aktivitas tertentu. ${ }^{1}$ Hasil perkiraan keluaran energi semua aktivitas dalam 24 jam kemudian ditotalkan sehingga menjadi total keluaran energi sampel dalam satu hari. Selanjutnya aktivitas fisik ini di kategorikan menjadi: Aktivitas ringan $<30 \%$ dari kebutuhan, Aktivitas sedang $30-50 \%$ dari kebutuhan, Aktivitas berat $>50 \%$ dari kebutuhan. ${ }^{1}$

\section{Data lingkar perut}

Data mengenai lingkar perut sebagai gambaran terhadap kejadian obesitas sentral dikumpulkan dengan metode pengukuran lingkar perut menggunakan meterline. Selanjutnya untuk mengetahui terjadinya risiko obesitas sentral dilakukan dengan membandingkan hasil pengukuran dengan standar lingkar perut yang telah ditentukan. Adapun kategori lingkar perut yaitu: pria: normal bila $<90,0 \mathrm{~cm}$, Berisiko bila $\geq 90,0 \mathrm{~cm}$. Wanita: Normal bila $<80,0 \mathrm{~cm}$, Berisiko bila $\geq 80,0 \mathrm{~cm} \cdot 3,9$

\section{Analisis Data}

Untuk mengetahui perbedaan tingkat asupan energi, lemak dan aktivitas fisik pada pada pasien rawat jalan berdasarkan risiko obesitas sentral dilakukan dengan analisis uji Independent t-test

\section{HASIL}

\section{Tingkat asupan Energi}

Tingkat asupan energi sampel diperoleh dari hasil analisa pada form SQ/FFQ pola konsumsi makanan pasien sehari-hari. Dari hasil penelitian diketahui bahwa rata-rata tingkat asupan energi sampel adalah 100,87 persen dengan tingkat asupan terendah 85,78 persen dan tertinggi 126,66 persen. Gambaran tingkat asupan energi sampel dapat dilihat pada Tabel 1.

\section{Tingkat asupan Lemak}

Tingkat asupan lemak sampel terendah adalah 87,39 persen dan tertinggi 131,84 persen dengan rata-rata 103,89 persen. Tingkat asupan lemak sampel sebagian besar pada kategori lebih $(55 \%)$ dikarenakan banyaknya sampel yang memiliki pola asupan sehari-hari tinggi lemak seperti mengonsumsi daging ayam, daging babi, fast food, dan pengolahan 
dilakukan dengan cara digoreng. Berikut adalah tabel tingkat asupan lemak yang disajikan pada Tabel 2.

\section{Aktivitas fisik}

Aktivitas fisik sehari diperoleh dari wawancara aktivitas selama satu hari, kemudian hasilnya berupa keluaran energi yang digunakan untuk setiap kegiatan dijumlahkan dan dibandingkan dengan standar kebutuhan sampel. Dari hasil analisa diperoleh rata-rata tingkat aktivitas fisik sampel adalah 45,31 persen dengan tingkat aktivitas fisik terendah 30,05 persen dan tertinggi 68,33 persen. Sebagian besar sampel memiliki tingkat aktivitas fisik yang sedang yaitu sebanyak 44 orang $(73,3 \%)$ (Tabel 3$)$.

Tabel 1

Distribusi Sampel Berdasarkan Tingkat asupan Energi

\begin{tabular}{lcc}
\hline Kategori Tingkat Konsumsi & $\mathrm{n}$ & $\%$ \\
\hline Sedang & 6 & 10,0 \\
Baik & 27 & 45,0 \\
Lebih & 27 & 45,0 \\
\hline
\end{tabular}

Tabel 2

Distribusi Sampel Berdasarkan Tingkat asupan Lemak

\begin{tabular}{lcc}
\hline Kategori Tingkat Konsumsi & $\mathrm{n}$ & $\%$ \\
\hline Sedang & 5 & 8,3 \\
Baik & 22 & 36,7 \\
Lebih & 33 & 55,0 \\
\hline
\end{tabular}

Tabel 3

Distribusi Sampel berdasarkan Tingkat Aktivitas Fisik

\begin{tabular}{lcc}
\hline Kategori Tingkat Aktivitas Fisik & $\mathrm{n}$ & $\%$ \\
\hline Sedang & 44 & 73,3 \\
Berat & 16 & 26,7 \\
\hline
\end{tabular}

Tabel 4

Distribusi Sampel berdasarkan Status Obesitas Sentral

\begin{tabular}{lccc}
\hline Status Obesitas Sentral & $\mathrm{n}$ & $\%$ & Rata-Rata Lingkar perut (cm) \\
\hline Tidak Berisiko & 30 & 50,0 & 78,9 \\
Berisiko & 30 & 50,0 & 85,2 \\
\hline
\end{tabular}


Tabel 5

Sebaran Tingkat Asupan Energi Sampel berdasarkan Status Obesitas Sentral

\begin{tabular}{lcccc}
\hline \multirow{2}{*}{ Asupan Energi } & \multicolumn{4}{c}{ Status Obesitas Sentral } \\
\cline { 2 - 5 } & \multicolumn{3}{c}{ Normal } & \multicolumn{3}{c}{ Berisiko } \\
\cline { 2 - 5 } & $\mathrm{n}$ & $\%$ & $\mathrm{n}$ & $\%$ \\
\hline Sedang & 2 & 6,7 & 4 & 13,3 \\
Baik & 21 & 70,0 & 6 & 20,0 \\
Lebih & 7 & 23,3 & 20 & 66,7 \\
\hline
\end{tabular}

Tabel 6

Sebaran Tingkat Konsumsi Lemak Sampel berdasarkan Status Obesitas Sentral

\begin{tabular}{lcccc}
\hline \multirow{2}{*}{ Konsumsi Lemak } & \multicolumn{4}{c}{ Status Obesitas Sentral } \\
\cline { 2 - 5 } & \multicolumn{3}{c}{ Normal } & \multicolumn{3}{c}{ Berisiko } \\
\cline { 2 - 5 } & $\mathrm{n}$ & $\%$ & $\mathrm{n}$ & $\%$ \\
\hline Sedang & 5 & 16,7 & 0 & 0 \\
Baik & 13 & 43,3 & 9 & 30,0 \\
Lebih & 12 & 40,0 & 21 & 70,0 \\
\hline
\end{tabular}

Tabel 7

Sebaran Tingkat Aktivitas Fisik Sampel berdasarkan Status Obesitas Sentral

\begin{tabular}{lcccc}
\hline \multirow{2}{*}{ Tingkat Aktivitas Fisik } & \multicolumn{4}{c}{ Status Obesitas Sentral } \\
\cline { 2 - 5 } \multicolumn{1}{c}{} & \multicolumn{3}{c}{ Normal } & \multicolumn{3}{c}{ Berisiko } \\
\cline { 2 - 5 } Sedang & 17 & 56,7 & 27 & 90,0 \\
Berat & 13 & 43,3 & 3 & 10,0 \\
\hline
\end{tabular}

\section{Obesitas Sentral}

Jumlah sampel yang memiliki risiko obesitas sentral adalah sebanyak 30 sampel dan yang normal sebagai pembanding sebanyak 30 orang. Dari hasil analisis (Tabel 4) diketahui bahwa rata-rata lingkar perut sampel berisiko adalah $85,2 \mathrm{~cm}$ dan yang normal adalah $78,9 \mathrm{~cm}$ dengan lingkar perut terpendek $59,0 \mathrm{~cm}$ dan terpanjang $115,0 \mathrm{~cm}$.

\section{Analisis Perbedaan Tingkat Konsumsi Energi Berdasarkan Status Obesitas Sentral}

Dari hasil analisis menggunakan uji Independent $\mathrm{t}$-test diperoleh nilai $\mathrm{t}=-2,42$ dengan signifikan $p=0,019$. Rata-rata tingkat asupan energi untuk sampel yang tidak berisiko adalah $97,74 \%$ dan berisiko $104 \%$. Karena nilai signifikan $<0,05$ maka disimpulkan bahwa ada perbedaan yang signifikan pada asupan energi antara sampel yang berisiko obesitas sentral dengan sampel yang tidak berisiko obesitas sentral. Perbedaan jelas terlihat pada sebaran tingkat asupan energi berdasarkan status obesitas sentral dimana sampel berisiko sebanyak 20 orang $(66,7 \%)$ memiliki asupan energi melebihi kebutuhan, sedangkan sampel tidak berisiko hanya sebanyak 7 orang $(23,3 \%)$ yang memiliki asupan energi melebihi kebutuhan (Tabel 5).

\section{Tingkat Konsumsi Lemak Berdasarkan Status Obesitas Sentral}

Dari hasil analisis menggunakan uji Independent t-test untuk melihat perbedaan tingkat asupan lemak berdasarkan status obesitas sentral diperoleh nilai $\mathrm{t}=-2,029$ dengan signifikan $p=0,047$. Rata-rata tingkat asupan lemak sampel yang tidak berisiko adalah 101,03 persen dan yang berisiko adalah 106,7 persen. Karena nilai signifikan nya $<0,05$ 
maka berarti terdapat perbedaan tingkat asupan lemak yang signifikan antara sampel yang berisiko obesitas sentral dan sampel yang tidak berisiko obesitas sentral. Perbedaan ini jelas terlihat pada tabel sebaran asupan lemak sampel menurut risiko obesitas sentral dimana dari sampel yang tingkat asupan lemaknya berlebihan, sebanyak 21 orang $(70,0 \%)$ termasuk katagori berisiko dan hanya 12 orang $(40,0 \%)$ termasuk katagori tidak berisiko (Tabel $6)$.

\section{Aktivitas Fisik Berdasarkan Status Obesitas Sentral}

Hasil analisis data menggunakan Independent $t$-test didapat nilai $t=2,83$ dengan signifikan $p=0,006$ maka nilai signifikan $<0,05$, berarti ada perbedaan tingkat aktivitas fisik sehari yang signifikan berdasarkan status obesitas sentral. Rata-rata tingkat aktivitas fisik sehari sampel yang tidak berisiko obesitas sentral yaitu 48,89 persen dan yang berisiko yaitu 41,72 persen. Perbedaan jelas terlihat pada tabel sebaran aktivitas fisik sehari sampel berdasarkan risiko obesitas sentral dimana pasien dengan risiko obesitas sentral hanya sebanyak 3 orang $(10 \%)$ yang memiliki aktivitas fisik berat, sedangkan pasien yang tidak berisiko obesitas sentral sebanyak 13 orang $(43,3 \%)$ yang memiliki aktivitas fisik berat. Untuk hasil selengkapnya dapat dilihat pada Tabel 7.

\section{BAHASAN}

Berdasarkan hasil analisa data terhadap variabel tingkat konsumsi energi dan risiko obesitas sentral dengan uji Independent t-test diperoleh nilai $\mathrm{t}=-2,42$ dengan signifikan $p=$ $0,019 \quad(<0,05)$ maka berarti ada perbedaan tingkat asupan energi yang signifikan antara pasien dengan risiko obesitas sentral dan yang tidak memiliki risiko obesitas sentral. Sebagian besar sampel dengan risiko obesitas sentral memiliki kebiasaan mengonsumsi makanan sumber energi tinggi seperti kue-kue, gula, dan sumber energi dari lemak. Jika dilihat pada Tabel 5, terdapat 21 orang $(70 \%)$ yang tidak berisiko obesitas sentral memiliki tingkat asupan energi yang baik dan hanya 6 orang (20\%) berisiko yang memiliki tingkat asupan energi yang baik. Hal ini membuktikan bahwa asupan energi pada sampel yang berisiko obesitas sentral dan yang tidak berisiko memiliki perbedaan yang bermakna.

Dari hasil penelitian diketahui pula sebagian besar sampel obesitas sentral memiliki kebiasaan mengkonsumsi kue-kue, gula, minuman manis dan makanan tinggi energi yang bersumber dari lemak. Makanan manis dapat meningkatkan berat tubuh dan lingkar perut. Hubungan ini diduga karena kombinasi antara makanan berlemak dengan makanan manis. Makanan manis sering kali kaya akan lemak. Gula digolongkan sebagai karbohidrat sederhana yang tersusun dari unsur karbon, hidrogen, dan oksigen. Gula paling banyak mengandung energi dan hanya sedikit mengandung vitamin dan mineral. Kelebihan konsumsi karbohidrat sederhana ini akan disimpan dalam bentuk glikogen dan lemak yang kemudian menyebabkan overweight dan obesitas. $^{3}$

Begitu pula dengan hasil analisa data terhadap variabel tingkat asupan lemak dengan risiko obesitas sentral diperoleh nilai $t=-2,029$ dengan signifikan $p=0,047 \quad(<0,05)$ maka berarti ada perbedaan asupan lemak yang bermakna antara sampel dengan risiko obesitas sentral dan yang tidak berisiko obesitas sentral. Hasil penelitian menunjukkan sebagian besar sampel kasus berisiko memiliki pola konsumsi lemak yang melebihi kebutuhan seperti pemilihan bahan makanan sumber protein hewani dan nabati yang dikonsumsi secara berlebihan, kecenderungan memilih makanan yang diawetkan, dan kebiasaan pengolahan makanan dengan cara digoreng menggunakan banyak minyak.

Berdasarkan hasil analisa data terhadap aktivitas fisik sehari dengan risiko obesitas didapat nilai $\mathrm{t}=2,83$ dengan signifikan $p=$ $0,006(<0,05)$ maka artinya ada perbedaan tingkat aktivitas fisik yang bermakna antara sampel yang memiliki risiko obesitas sentral dan sampel yang tidak berisiko obesitas sentral. Jika dilihat pada Tabel 7 diketahui pasien dengan risiko obesitas sentral hanya 3 orang (10\%) yang memiliki aktivitas fisik di atas $50 \%$ atau aktivitas berat, sedangkan pasien yang tidak berisiko obesitas sentral sebanyak 13 orang $(43,3 \%)$ yang memiliki aktivitas fisik berat. Hal ini membuktikan bahwa terdapat perbedaan aktivitas fisik yang bermakna antara sampel berisiko dan tidak berisiko obesitas sentral. 
Hasil analisa ini sejalan dengan hasil penelitian Nadhiroh tentang perbedaan pola makan dan aktivitas fisik antara remaja obesitas dengan non obesitas menggunakan uji Mann Whitney menyebutkan bahwa ada perbedaan yang bermakna pada tingkat asupan energi, karbohidrat, protein dan lemak. Begitu juga dengan aktivitas fisik juga menunjukkan ada perbedaan yang bermakna. ${ }^{6}$

Hasil penelitian menunjukkan bahwa kelebihan asupan energi dan lemak pada sebagian besar kelompok berisiko tidak diimbangi dengan tingkat aktivitas fisik yang cukup. Sebagian besar sampel kasus hanya memiliki aktivitas fisik yang sedang. Sedangkan pada kelompok yang normal, sebagian dari mereka memiliki tingkat aktivitas fisik yang berat.

Dalam penelitian Zahra terhadap pegawai pemerintahan di kantor Bupati Kabupaten Jeneponto tahun 2012 diperoleh pegawai dengan asupan gula sukrosa tinggi memiliki risiko 4,2 kali lebih besar mengalami obesitas sentral daripada pegawai dengan asupan gula sukrosa yang cukup. Asupan lemak tinggi juga memiliki risiko 9,3 kali lebih besar mengalami obesitas sentral daripada yang memiliki asupan lemak cukup.

Beberapa penelitian sebelumnya menemukan bahwa peningkatan risiko kesehatan lebih berhubungan dengan obesitas sentral dibandingkan dengan obesitas umum. Obesitas sentral meningkatkan risiko hipertensi, dislipidemia, diabetes, dan sindrom metabolik pada laki-laki dan perempuan. ${ }^{8}$

\section{SIMPULAN DAN SARAN}

\section{Simpulan}

Tingkat asupan energi pada sampel yang berisiko sebagian besar termasuk dalam kelompok asupan kategori lebih. Tingkat asupan energi pada sampel yang normal sebagian besar termasuk pada kelompok asupan kategori baik. Tingkat asupan lemak pada sampel yang berisiko sebagian besar termasuk pada asupan yang lebih. Tingkat aktivitas fisik pada sampel yang berisiko sebagian besar termasuk aktivitas sedang. Ada perbedaan tingkat asupan energi, tingkat asupan lemak, dan aktivitas fisik, berdasarkan status obesitas sentral pada sampel pasien rawat jalan di RSUD Wangaya Denpasar.

\section{Saran}

Penderita obesitas sentral agar melaksanakan pola hidup sehat yaitu dengan cara melakukan aktivitas fisik berupa olahraga yang tepat dan teratur serta pengaturan pola makanan yang tepat untuk mengurangi risiko terjadinya penyakit degeneratif sebagai akibat dari terjadinya obesitas sentral.

\section{UCAPAN TERIMA KASIH}

Ucapan terimakasih ditujukan kepada Direktur RSUD Wangaya dan staf yang telah mendukung dan mengijinkan penelitian ini sehingga dapat terlaksana dengan baik.

\section{RUJUKAN}

1. Centre for Disease Control (CDC). Physical Activity for Everyone: Guidelines: Adults Available from: http://www.cdc.gov/physicalactivity/eve ryone/guidelines/adults.

2. Drapeau V, Jean-Pierre Després, Claude Bouchard C, Lucie Allard L, Guy Fournier G, Claude Leblanc C, et al. Modifications in food-group consumption are related to long-term body-weight changes. Am J Clin Nutr. 2004; 80(1) : 29-37

3. Hartono A. Terapi Gizi dan Diet Rumah Sakit. Jakarta: Penerbit Buku Kedokteran, 2006.

4. Li C, Ford ES, McGuire LC, Mokdad $\mathrm{AH}$. Increasing trends in waist circumference and abdominal obesity among U.S. adult. Obesity.2007;15(1):216-224

5. Lemeshow S, Lwanga A. Besar Sampel dalam Penelitian Kesehatan. Yogyakarta: Gadjah Mada Universitas Press, 1997.

6. Nadhiroh SR, Suryaputra K. Perbedaan Pola Makan dan Aktivitas Fisik Antara Remaja Obesitas dengan Non Obesitas. Makara Kesehatan.2012;16(1):45-50

7. Supariasa, IDN., Bakri B, Ibnu-Fajar. Penilaian Status Gizi. Jakarta : Penerbit Buku Kedokteran EGC, 2012.

8. Wildman, RP, GuD.Reynolds K, Duan X, He J. 2004. Appropriate body mass index and waist circumference cut offs 
to categorized of overweight and central adiposity among Chinese adults. Am J Clin Nutr.2004; 80(5): 1129-1136
9. World Health Organization. Obesity: Preventive and Margering the Global Epidemic Report of a WHO Scientific Group. Geneva: WHO, 2000. 